\title{
Occurrence of gastrointestinal parasitic diseases of swine in different production phases in commercial pig farms from the State of Santa Catarina, southern Brazil
}

\author{
[Ocorrência de parasitoses gastrointestinais dos suínos, nas diferentes fases de produção, em \\ granjas comerciais de Santa Catarina, Brasil] \\ B. Pradella ${ }^{1}$, K.F. Molosse ${ }^{1}$, M. Menin ${ }^{1}$, B. Matzembacker ${ }^{1}$, N. Biondo ${ }^{2}$, D.L. Vanazzi ${ }^{2}$, \\ N. Baldasso ${ }^{2}$, P.E. Bennemann ${ }^{3}$, A. Prestes ${ }^{4}$, G. Camillo ${ }^{1 *}$ \\ ${ }^{1}$ Laboratorio de Parasitologia - Universidade do Oeste de Santa Catarina - Xanxerê, SC \\ ${ }^{2}$ Laboratório de Patologia Veterinária - Universidade do Oeste de Santa Catarina - Xanxerê, SC \\ ${ }^{3}$ Laboratório de Reprodução Animal - Universidade do Oeste de Santa Catarina - Xanxerê, SC \\ ${ }^{4}$ Universidade do Oeste de Santa Catarina - Xanxerê, SC
}

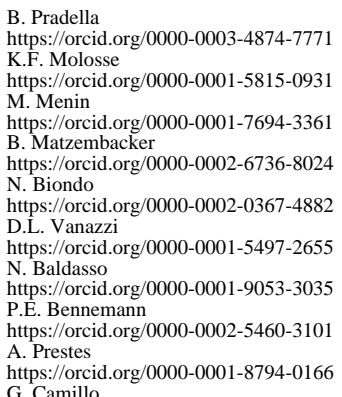
K.F. Molosse https://orcid.org/0000-0001-5815-0931 M. Menin https://orcid.org/0000-0001-7694-3361 B. Matzembacker https://orcid.org/0000-0002-6736-8024 h. Biondo https://orcid.org/0000-0002-0367-4882 D.L. Vanazzi https://orcid.org/0000-0001-5497-2655 N. Baldasso

https://orcid.org/0000-0001-9053-3035 P.E. Bennemann https://orcid.org/0000-0002-5460-3101 A. Prestes

https://orcid.org/0000-0001-8794-0166

\begin{abstract}
Gastrointestinal parasites are important, since they can cause a decrese in the performance of swine. The occurrence of parasites in pig farms can create economic losses such as reduction in the value of carcasses and increasing expenses with medicines and veterinary assistance. This study aimed at investigating the occurrence of intestinal parasites in different phases of production reared pigs in intensive prodution systems in the western region of the State of Santa Catarina. A total of 403 fecal samples were analyzed, of which $51.86 \%$ were positive for one or more parasites in different phases of production. Finishing pigs had the highest prevalence of parasites $(60.19 \%)$ followed by nursery pigs $(55.44 \%)$, pigs in breading sows $(50.49 \%)$, and suckling piglets $(40.81 \%)$. Strongylida parasites had higher occurrence $(28.78 \%)$, and were also the most frequent in the finishing, breading sows, and nursery phases. Coccidia were more occurrent in suckling piglets. This study highlights the need of implementing suitable antiparasitic control measures in all phases of swine production associated with a surveillance system for the diagnosis of endoparasite infection in pigs. Our results demonstrate that endoparasites are highly occurring in pigs, even in intensive system animals on technified farms.
\end{abstract}

Keywords: endoparasites, finishing pigs, suckling piglets, nursery, sheather

\section{RESUMO}

Parasitas gastrointestinais são importantes, pois podem causar uma diminuição no desempenho dos suínos. A ocorrência de parasitas em granjas de suínos pode gerar perdas econômicas, como redução no valor das carcaças e aumento de gastos com medicamentos e assistência veterinária. Este estudo teve como objetivo investigar a ocorrência de parasitas intestinais nas diferentes fases de produção de suínos criados em sistemas intensivos, na região oeste do estado de Santa Catarina. Foram analisadas 403 amostras fecais, das quais 51,86\% foram positivas para um ou mais parasitas nas diferentes fases de produção. Os suínos de terminação apresentaram a maior prevalência de parasitas (60,19\%), seguidos por suínos de creche $(55,44 \%)$, suínos em gestação $(50,49 \%)$ e leitões em lactação (40,81\%). Parasitas da ordem Strongylida tiveram maior ocorrência $(28,78 \%)$ e também foram os mais frequentes nos estágios de terminação, reprodução e creche. Coccídios foram mais ocorrentes em leitões lactentes. Este estudo destaca a necessidade de implementar medidas de controle antiparasitário adequadas em todas as fases da produção suína, associadas a um sistema de vigilância para o diagnóstico de infecção por endoparasitas em suínos. Os resultados demonstram que os endoparasitas são altamente ocorrentes em suínos, mesmo em animais de criação intensiva em granjas tecnificadas.

Palavras-chave: endoparasitas, terminação, leitões lactantes, crechário, Sheather

Recebido em 17 de dezembro de 2019

Aceito em 11 de maio de 2020

*Autor para correspondência (corresponding author)

E-mail: giovana.camillo@unoesc.edu.br 


\section{INTRODUCTION}

Pig farming is a competitive and highly technified activity. However, it faces challenges such as sanitary problems. In general, bacterial and viral diseases are the subject of much debate and parasitic diseases are not considered by every producer as a cause of economic losses in pig. Despite the mainly subclinical infections, every producer should be aware of their presence and the resulting losses (Mundt et al., 2006; Ózsvári, 2018). Likewise, clinical signs are not specific and often are not observed in infected swine (Nishi et al., 2000). In animals affected by gastrointestinal parasites, losses in performance may occur, mainly because they favor the occurrence of secondary infections by opportunistic pathogens (Linhares et al., 2012). The economic losses associated with endoparasitic infections are due to reduction in feed efficiency, low number of piglets born, low weight of the offspring, low weight at weaning, reduced fertility, and interference in the immune response to vaccines (Steehard et al., 2009; Barbosa et al., 2015).

Information on the major parasitic diseases of swine is available in the literature. However, the data are outdated and refer to extensive breeding systems (Reboucas et al., 1992; Martins et al., 1993). For the swine intensive production systems, studies are scarce and were published more than a decade ago (Nishi et al., 2000, Hoff et al., 2005; Fiuza et al., 2008). Endoparasites of major ocurrence in swine farming may occur in the different phases of production and are cited such as the protozoan organisms Cystoisospora suis (Calderaro et al., 2001; D'Alencar et al., 2006; Sartor et al., 2007) and Cryptosporidium spp. (Freire et al., 1996; Nishi et al., 2000; Calderaro et al., 2001; Fiuza et al., 2008). Among the helminths, the most occurrent ones are the nematodes Ascaris suum (Nishi et al., 2000; Hoff et al., 2005; D'Alencar et al., 2006; Aguiar, 2009; Dias et al., 2011; Barbosa et al., 2015) and those of the order Strongylida, such as Trichostrongylus axei, Hyostrongylus sp. and Oesophagostomum sp. (Nishi et al., 2000; Hoff et al., 2005; Pinto et al., 2007; Aguiar, 2009; Antunes et al., 2011; Barbosa et al., 2015; Carreiro et al., 2016).

In addition to these parasites, pigs are considered the main reservoir of the ciliate Balantidium coli, which can infect humans, especially those who work in agriculture (Barbosa et al., 2016). Humans are also considered reservoirs of the protozoan parasite Entamoeba spp. in cases of swine that are infected with this amoebozoa (Solaymani-mohammadi and Petri, 2006). Based on the lack of information in the literature for current swine production systems, especially in the state of Santa Catarina, south Brazil, a state which is considered an important pork producer in the country, the present study aimed to identify the most common gastrointestinal parasites in the different phases of production in an intensive pig production system.

\section{MATERIALS AND METHODS}

Between September 2017 and February 2018, intensive pig production farms were selected random in the western region of Santa Catarina, southern Brazil, for this survey. Fecal samples were collected during the following phases: breeding (breeding and farrowing sows), suckling (piglets 5 to 28 days of age), nursery (animals 28 to 63 days of age), and grower-finishing (animals with 64 days of age to slaughter age). The selection of the farms was random, without evaluation of the occurrence of diarrhea, use of previous anthelmintic treatment, or any other factor. Fourteen farms were included in this study and consisted of piglets (5), nursery pigs (4), and finishing pigs (5).

Each one owner completed the form wich informations included the structure of the farms and epidemiological data of the production system. The collected data was on the occurrence of parasitic diseases, prevalence of internal parasite infections, diagnosis of endoparasitic diseases, use of anthelmintics, type of premise, management methods of cleaning and disinfection facilities, implementation of all-in-all-out biosecurity protocol, and water source of the farm. The owners signed a consent form, which was in agreement with the survey. For the collection of fecal samples, animals were randomly selected, and stool specimens were collected directly from the rectal ampulla (Antunes et al., 2011). Approximately $7 \mathrm{~g}$ of faeces were sampled from each animal. Stool specimens were put into individual plastic bags, labeled with accession numbers, and stored in isothermal boxes with ice. Fecal specimena were submitted to the Veterinary Parasitology Laboratory of the university within 
24 hours of the sample collection for parasitological examination.

For the parasitological analysis of the fecal samples, the modified Gordon and Whitlock technique (EPG) and the Sheather technique were performed. The EPG technique was proposed for breeding sows, grower pigs, and finishing pigs, in order to quantitatively evaluate stool samples (D'alencar et al., 2006). The Sheather technique (Centrifugal flotation Sheather (1923) modified by Huber et al. (2003) was used for the qualitative analysis of the fecal specimens from swine in all production phases, mainly for the the search of coccidia. Glass slides were screened under a light microscope (NIKON, Eclipse - E200). Fecal samples analyzed by the Sheather technique (at $100 \mathrm{x}$ or $400 \mathrm{x}$ magnification) were considered positive when a developmental phase of the endoparasite was found (i.e., a cysts, a oocyst, a trophozoite, or an egg). Eggs of parasites fro the order Strongylida and coccidian oocysts were quantified using the EPG technique (at 100x magnification). This study was conducted according to the regulations for the use of animals in research and was approved by the Ethics Committee (CEUA) of the Santa Catarina Western University (UNOESC), Xanxerê, SC, Brazil under (permit $n^{\circ}$ 27/2017). The results of the laboratory analyses were submitted to a descriptive analysis of the data. The results were tabulated according to the phase of occurrence.

\section{RESULTS AND DISCUSSION}

A total of 403 faecal samples from swine in different production phases were examined: 103 samples from growth-finishing, 101 samples from breeding sows, 101 samples from nursery pigs, and 98 samples from suckling piglets. All fecal samples were tested by the Sheather and Gordon Withlock modified techniques, in which 209/403 $(51.86 \%)$ and $46 / 403(11.66 \%)$ were positive for endoparasites, respectively. The EPG technique was used to quantify the positive samples in which a mean of 127 feces EPG was obtained in 46 positive samples, and oocysts with a mean of 5,406 OoPG in 8 positive samples. Although the goal of this technique is quantification, a lower occurrence of eggs, cysts, and oocysts may be detected when compared with the Sheather technique. Both are floating techniques. However, according to the findings published by Hoff et al. (2005), the Sheather technique is more sensitive for the detection of oocysts and protozoan cysts and helminth eggs.

Using the Sheather technique for the parasitological examination of fecal samples from swine in different production phases, $51.86 \%$ tested positive (Table 1). Studies published by a number of authors in Brazil including a survey carried out by Barbosa et al. (2015) show a similar prevalence $(59.1 \%)$ of swine infected with internal parasites in the State in Rio de Janeiro, southeast Brazil. Other researchers found prevalences of $38.6 \%$ and $39.7 \%$ in the states of Minas Gerais and São Paulo, southeastern region of the country, respectively (Nishi et al., 2000). These studies were conducted in intensive production systems, and the Sheather technique was the method used for the parasitological survey.

The results presented in Table 1 show a higher prevalence of endoparasites in finishing pigs $(60.19 \%)$ followed by nursery pigs (55.44\%), breeding sows $(50.49 \%)$, and suckling piglets $(40.81 \%)$. The prevalence of internal parasites in the finishing was similar to the $62.9 \%$ that was found by Antunes et al. (2011) who used only the EPG technique, and the $59.1 \%$ reported by Barbosa et al. (2015) that used other methods for the parasitological examination of feces including the Ritchie, Faust, Lutz, and Sheather assays and the direct smear. Swine in the breeding sows and nursery phases had prevalences of internal parasite infections lower than the $76.19 \%$ found by Nishi et al. (2000) in the breeding phase, and prevalences higher than the $29.31 \%$ found in nursery pigs. In the study carried out by Barbosa et al. (2015), $69.19 \%$ of the total of parasites were detected in sows in the breeding phases, considering only the technified farms and fecal samples from lactating and breeding sows.

The fact that endoparasitic infections are relatively common in swine operations may be associated with coprophagia since the transmission of the major internal parasites found in finishing pigs, nursery pigs, and breeding sows in reproductive age, is fecal-oral. It consists of the ingestion of eggs or oocysts from feces from infected animals that are present in the environment (Taylor et al., 2010; Monteiro, 2011). Even in farms with technified management and modern infrastructure e.g. slatted floor system, daily improper, faulty cleaning of 
facilities may occur. According to the findings published by Antunes et al. (2011), regular cleaning of intensive production systems in swine farming is an important factor to reduce environmental contamination by feces reducing, therefore the prevalence of parasitic infections. These authors compared the results of their study with the results from studies carried out in extensive production systems. Based on the prevalence of endoparasitic diseases in each production phase (Table 1), it is suggested that infection occurs during the suckling phase. Piglets become infected as they ingest eggs or oocysts while suckling on the mammary glands of infected sows which are contaminated with fecal material (fecal-oral transmission). Such correlation may be based on the life cycle of parasites of the order Strongylida, which prepatent period may vary from 3 weeks to 4 weeks (Urquhart, 1998). Thus, in the next production - nursery and finishing - there may be an increase in the number of positive animals due to the fecal egg or oocyst shedding that occurs and contaminates the environment.

Therefore, adequate control measures should be implemented in order to prevent parasitic diseases in animals at the breeding sows, specifically breeding sows. Linhares et al. (2012) published guidelines for anthelmintic treatment in swine farms. These authors recommend that animals be treated with anthelmintics 7 to 10 days before being transferred to gestation crates. In our study, it was observed that during the breeding phase, females were not subjected to such management. The swine herds were dewormed every 6 months regardless of the time when sows were housed in maternity pens.

Table 1. Intestinal parasites of pigs found in different production phases in farms from the western region of the State of Santa Catarina, south Brazil

\begin{tabular}{|c|c|c|c|c|c|c|c|c|}
\hline $\begin{array}{l}\text { Production } \\
\text { Category }\end{array}$ & $\begin{array}{l}\text { Number } \\
\text { of fecal } \\
\text { samples }\end{array}$ & $\begin{array}{c}\text { Strongylid } \\
\mathrm{n} \\
(\mathrm{n} \%)\end{array}$ & $\begin{array}{c}\text { A. suum } \\
\mathrm{n} \\
(\mathrm{n} \%)\end{array}$ & $\begin{array}{c}\text { Coccidia } \\
\mathrm{n} \\
(\mathrm{n} \%)\end{array}$ & $\begin{array}{c}\text { Trichuris } \\
\text { spp. } \\
\text { n } \\
(\mathrm{n} \%)\end{array}$ & $\begin{array}{c}\text { Balantidium } \\
\text { spp. } \\
\text { n } \\
(\mathrm{n} \%)\end{array}$ & $\begin{array}{c}\text { Entamoeba } \\
\text { spp. } \\
\mathrm{n} \\
(\mathrm{n} \%)\end{array}$ & $\begin{array}{l}\text { Total of } \\
\text { positive } \\
\text { samples }\end{array}$ \\
\hline $\begin{array}{l}\text { Breeding } \\
\text { sows }\end{array}$ & 101 & $\begin{array}{c}32 \\
(31.68 \%)\end{array}$ & $\begin{array}{c}1 \\
0.99 \%)\end{array}$ & $\begin{array}{c}4 \\
(3.96 \%)\end{array}$ & 0 & $\begin{array}{c}5 \\
(4.95 \%)\end{array}$ & $\begin{array}{c}9 \\
(8.91 \%)\end{array}$ & $\begin{array}{c}51 / 101 \\
(50.49 \%)\end{array}$ \\
\hline Nursery & 101 & $\begin{array}{c}27 \\
(26.73 \%)\end{array}$ & $\begin{array}{c}2 \\
(1.98 \%)\end{array}$ & $\begin{array}{c}9 \\
(8.91 \%)\end{array}$ & $\begin{array}{c}1 \\
(0.99 \%)\end{array}$ & $\begin{array}{c}8 \\
(7.92 \%)\end{array}$ & $\begin{array}{c}9 \\
(8.91 \%)\end{array}$ & $\begin{array}{c}56 / 101 \\
(55.44 \%)\end{array}$ \\
\hline $\begin{array}{l}\text { Suckling } \\
\text { Piglet }\end{array}$ & 98 & $\begin{array}{c}8 \\
(8.16 \%)\end{array}$ & $\begin{array}{c}1 \\
(1.02 \%)\end{array}$ & $\begin{array}{c}26 \\
(26.53 \%)\end{array}$ & 0 & $\begin{array}{c}2 \\
(2.04 \%)\end{array}$ & $\begin{array}{c}3 \\
(3.06 \%)\end{array}$ & $\begin{array}{c}40 / 98 \\
(40.81 \%)\end{array}$ \\
\hline Finishing & 103 & $\begin{array}{c}49 \\
(47.57 \%)\end{array}$ & 0 & $\begin{array}{c}3 \\
(2.91 \%)\end{array}$ & 0 & $\begin{array}{c}3 \\
(2.91 \%)\end{array}$ & $\begin{array}{c}7 \\
(6.79 \%)\end{array}$ & $\begin{array}{c}62 / 103 \\
(60.19 \%)\end{array}$ \\
\hline Total & 403 & $\begin{array}{c}116 / 403 \\
(28.78 \%)\end{array}$ & $\begin{array}{c}4 / 403 \\
(0.99 \%)\end{array}$ & $\begin{array}{c}42 / 403 \\
(10.42 \%)\end{array}$ & $\begin{array}{c}1 / 403 \\
(0.24 \%)\end{array}$ & $\begin{array}{c}18 / 403 \\
(4.46 \%)\end{array}$ & $\begin{array}{c}28 / 403 \\
(6.94 \%)\end{array}$ & $\begin{array}{c}209 / 403 \\
(51.86 \%)\end{array}$ \\
\hline
\end{tabular}

In addition, when the finishing, breeding and nursery were evaluated, parasites of the order Strongylida were the ones with the highest prevalence. In a study carried out by Barbosa et al. (2015), industrial and domestic farms were assessed, the authors found only $5.2 \%$ of fecal samples positive for strongilids in pigs from nontechnified farms. However, in the nursery and breeding, the results in the present study were higher than those of the studies conducted in the state of São Paulo (1.20\%) and Minas Gerais (15.87\%), southeast Brazil, by Nishi et al. (2000) using the Sheather technique.
One of the factors related to the higher prevalence rate of parasites of the order Strongylida may be explained by the fact that this particular order comprises a large number of genera (Monteiro, 2011). The morphology of strongylid eggs are very similar between species of parasites. Therefore, it is difficult to differentiate one helminth species from the other based on the techniques used and under the light microscope. Besides, coproculture should be performed for the identification of eggs to the species level. Coproculture was not performed in the present study though. 
The high prevalence of parasitic infections in the farms studied has a major negative impact on the development of animals due to a decrease in the absorption of nutrients in the small intestine (Hoff et al., 2005). In addition, animals with diarrhea may lose large amounts of water through feces and become dehydrated. They may ultimately die usually due to parasitic coinfections or concomitant infections with opportunistic bacterial or viral pathogens that make the disease more severe and often fatal (Jesus \& Müller, 2000; Hoff et al., 2005).

Another important parasite found in the nursery and breeding production phases but in a lower prevalence was the protozoan parasite Entamoeba spp. (Table 1). There are few studies about this amoebozoan organism. However, the prevalence rates found in the present study are similar to the $10.26 \%$ that was found in the study published by Barbosa et al. (2015). In the study conducted by these authors, pigs were evaluated in the breeding phase (lactating and breeding sows). A prevalence of $3.7 \%$ was found in the survey carried out by Antunes et al. (2011) in the finishing phase using the EPG technique. Humans are reservoirs of Entamoeba and therefore play a role in the epidemiology of the animal disease. This pathogen may cause the formation of abscesses in internal organs and also causes dysentery in swine. The control of this protozoan organism is based on good sanitary practices of the individuals including veterinarians, producers and staff that handle these animals on a daily basis (Linhares et al., 2012).

The protozoan parasite Balantidium spp. was found in the breeding sow, nursery, and finishing phases at a lower prevalence. In studies conducted by Nishi et al. (2000) and Barbosa et al. (2015), higher prevalences of Balantidium spp. were found in the breeding $(42.85 \%$ and $46.87 \%$, respectively) and nursery phase. Nishi et al. (2000) also found a higher prevalence of Balantidium spp. (14.85\%) compared with the findings of our study. Steffen et al. (2010) and Antunes et al. (2011) evaluated only finishing pigs and found a larger number of animals positive for the ciliate alveolate, i.e. $54.7 \%$ and $98.1 \%$, respectively. The discrepancy in the results of each survey and the lower detection of positive animals in the present study may be related to the fact that the techniques used for the detection of Balantidium in stool specimens were different in each of these studies.

The former group of authors Steffen et al. (2010), used centrifugation/flotation methods, whereas the latter research group Antunes et al. (2011), examined the stool samples using the fecal sedimentation assay. In a study published by Barbosa et al. (2016) in which the performance of different parasitological techniques for the search of Balantidium spp. in fecal samples were assessed, the Sheather method presented the lowest sensitivity compared with other methods. Therefore, the variation in the results in each study may have been due to the use of different methods in the search of this protozoan organism in fecal samples. The prevalence of Balantidium was considered low in our survey. Despite the fact that this ciliate is considered a commensal organis of the gastrointestinal tract of pigs, it may cause focal lesions in the intestines of swine as a opportunistic pathogen. Its major importance is related to public health since it may cause enteric disease in humans (Barbosa et al., 2016).

Other parasites detected less frequently in nursery pigs were Trichuris spp. and A. suum (Table 1). Hoff et al. (2005) examined feces from animals of all ages and found a prevalence of $0.5 \%$ for both nematode infections. There are few published reports of Trichuris infections in swine, and these refer to the occurrence of this helminth infection in non-technified pig farms. With regard to $A$. suum, Nishi et al. (2000) found $0.80 \%$ of fecal samples positive for this roundworm in nursery pigs. This finding is similar to ours. Eggs of $A$. suum were found in only one suckling piglet (Table 1). This is probably the result of the ingestion of eggs of the parasite from feces of infected adult females.

This may occur since in natural infections this parasite would not be present in the feces as the pre-patent period of this protozoan organism is between 7 and 9 weeks (Taylor et al., 2010). Ascaridiasis is considered one of the most important parasitic diseases in swine. It causes economic losses to the swine industry as it affects the development of animals and causes lesions in internal organs such as the liver and small intestine resulting in the condemnation of viscera and carcasses in slaughterhouses (Linhares et al., 2012). In addition, researchers have suggested that there may be an association between vaccine 
failures and A. suum infection in pigs (Steenard $e t$ al., 2009).

A high prevalence of coccidia (26.53\%) was observed in suckling piglets (Table 1). This prevalence rate is similar to the one published by Sayd and Kawazoe (1996) and Calderaro et al. (2001), and higher than the one found by Barbosa et al. (2015) (19.2\%). The Sheather technique was used in these studies which suggest that the method used to detect protozoan oocysts in stool specimens had no influence on the data found in each of these studies. This protozoan parasite was found in $80 \%(4 / 5)$ of maternity farms. This prevalence is similar to the $82 \%$ prevalence rate for coccidian infection that was found by Sayd and Kawazoe (1996). Taylor et al. (2010) suggest that adult females can act as carriers of this protozoan infection by shedding oocysts in feces. Feces are the source of contamination of the environment by eggs and oocysts and may be ingested by the piglets (fecal-oral transmission).

However, in a horizontal study conducted by Sotiraki et al. (2007), the authors reported that sows do not play an important role in the transmission of coccidian parasites to the piglets. These researchers did not find a correlation between the shedding of oocysts in the feces of these females and the occurrence of infection in piglets. Another important factor that contributes for the occurrence of coccidia in swine in this production phase is the intensive system where a large number of animals are confined to one area and therefore the population density is high. In addition, faulty cleaning and disinfection favor sporulation of oocysts in the facility contributing to increased environmental contamination (Skampardonis et al., 2012). Immunity against coccidia is acquired from previous infections, and both cellular and humoral responses are involved (Urquhart, 1998).

The major importance of coccidia in piglets is related to the occurrence of pigs that do not grow well and have to be removed from the herd, and increased expenses with drugs (Linhares et al., 2012). Currently, the main control measure of coccidiosis in pigs is the use of oral toltrazurilbased coccidiostats in suckling piglets. This is a prophylactic measure usually carried out in technified farms. However, to obtain more effective results, the antiprotozoal medication should be dosed on the third day of life of the piglet. This schedule of administration of the drug is based on the life cycle of the parasite (Skampardonis et al., 2012). Although less frequently, coccidia were also observed in fecal samples from animals in the nursery and breeding phases.

This prevalence is lower than the $46.87 \%$ found by Barbosa et al. (2015), possibly because these authors tested feces from a smaller number of farms in comparison to the larger number of stool specimens and farms visited in our study. The difficulty in diagnosing coccidia by direct fecal examination may account for the low prevalence of coccidia found in the nursery, breeding, and finishing phases in this survey. This may be due to the intermittent excretion of oocysts in faeces. Oocysts are shed in stools mostly during stressful situations or low immunity and have an important correlation with adult animals which act as carriers of the infection (Sayd and Kawazone, 1996).

Based on the analysis of the data retrieved from the survey answered by producers, we noticed that regular examination of fecal samples for the laboratory diagnosis of helminthiases is not a common practice in swine operations. Another important point to be considered is related to the sanitary management of the farms tested in the present study. Although all finishing farms adopted cleaning and disinfection measures and a sanitary void between batches of at least 7 days, a high prevalence of parasites was still observed. This fact may be associated to inefficient management of daily cleaning of premises as well as parasitic resistance to anthelmintics which is in agreement with the study of Nishi et al. (2000). In addition, all the animals evaluated in the finishing phase were fed a ration initially medicated with ivermectin.

The effectiveness and timing of this treatment are unclear. Among the five finishing farms assessed, $100 \%$ had one or more parasitic diseases, with no difference in this prevalence in terms of the population size in the farms. Adequate control of endoparasites is important in order to reduce environmental contamination with eggs, cysts, trophozoites, and oocysts shed in the feces which are the main source of infection for animals. Therefore, a future horizontal study is necessary to monitor the factors involved in the infection of pigs as well as to assess the effectiveness of 
anthelmintics in association with management and disinfection practices in the facilities.

\section{CONCLUSIONS}

The results of the present study show that the prevalence of internal parasites in intensive swine system in different production phases from the State of Santa Catarina, south Brazil, is high.

\section{ACKNOWLEDGMENTS}

The authors thank the Santa Catarina University scholarship program (UNIEDU) for financial support, and the Unoesc institution (Universidade do Oeste de Santa Catarina).

\section{REFERENCES}

AGUIAR, P.C. Aspectos epidemiológicos das parasitoses gastrintestinais de suínos naturalizados de criações familiares do Distrito Federal. 2009. 100f. Dissertação (Mestrado em Saúde Animal) - Universidade de Brasília, Brasília, DF.

ANTUNES, R.C.; CARRAZZA, L.G.; SANT'ANA, D.S. et al. Prevalência de parasitos gastrintestinais em leitões de terminação relacionada com densidade de alojamento e sexo. Pubvet, v.5, p.1019-1026, 2011.

BARBOSA, A.S.; BASTOS, O.M.P.; UCHOA, C.M.A. et al. Comparasion of Five parasitological techniques for laboratory diagnosis of Balantidium coli cysts. Rev. Bras. Parasitol. Vet., v.25, p.286-292, 2016.

BARBOSA, A.S; BASTOS, M.P.; DIB, L.V.; SIQUEIRA, M.P. et al. Gastrointestinal parasites of swine raised in different management systems in the State of Rio de Janeiro, Brazil. Pesqui. Vet. Bras., v.35, p.941-946, 2015.

CALDERARO, F.F.; BACCARO, M.R.; MORENO, A.M. et al. Frequência de agentes causadores de enterites em leitões lactantes de sistemas de Produção de suínos do estado de São Paulo. Arq. Inst. Biol., v.68, p.29-34, 2001.

CARREIRO, C.C.; COELHO, C.D.; JORGE, J.L.B.P. et al. Parasitas intestinais em suínos confinados em uma criação no município de Pinheiral, RJ. Rev. Bras. Med. Vet., v.38, p.117$122,2016$.
D’ALENCAR, A.S.; FAUSTINO, M.A.G.; SOUSA, D.P. et al. Infecção por helmintos e coccídios em criação de suínos de sistema confinado localizada no município de Camaragibe-PE. Ciênc. Vet. Tróp., v.6, p.79-86, 2006.

DIAS, A.S.; TANURE, A.M.; MANHÃES, H.G.V.C. Ocorrência de Ascaris suum em suínos abatidos na Zona da Mata, Minas Gerais. Braz. J. Vet. Res. Anim. Sci., v.48, p.101-106, 2011.

FREIRE, R.L.; BRITO, B.G.; LEITE, D.M.G.; VIDOTTO, O. Ocorrência de Cryptosporidium spp. em leitões com diarreia em granjas suinoculturas do sudoeste do Paraná. Semin. Cienc. Agrar. v.17, p.38-40, 1996.

FUIZA, V.R.S.; CONSENDEY, R.I.L.; OLIVEIRA, F.C.R. Criptosporidiose suína associada aos sistemas de produção no estado do Rio de Janeiro. Rev. Bras. Parasitol. Vet., v.17, p.224-229, 2008.

GORDON, H.M.; WITHLOK HVA. New techinique for counting nematode egg in sheep faeces. Commonwealth Sci. Ind. Res. Org., v.12, p.50-52, 1939 .

HOFF, G.; SILVA, A.S.; MONTEIRO, S.G. Avaliação do parasitismo e comparação de técnica de análise fecal em suínos de granjas da região oeste do estado de Santa Catarina. Rev. Fac. Zootec. Vet. Agron, v.12, p.106-115, 2005.

HUBER, F.; BOMFIM, T.C.; GOMES, R.S. Comparação da eficiência da técnica de sedimentação pelo formaldeído-éter e da técnica de centrífugo-flutuação modificada na detecção de cistos de Giardia sp. e oocistos de Cryptosporidium sp. em amostras fecais de bezerros. Rev. Bras. Parasitol. Vet., v.12, p.135137, 2003.

JESUS, L.P.; MULLER, G. Helmintos parasitos do estômago de suínos na região de Pelotas, RS. Rev. Bras. Agrocienc., v.6, p.181-187, 2000.

LINHARES， G.C.F.; SOBESTIANSKY， J.; LINHARES, D. et al. Endoparasitoses. In: SOBESTIANSKY J, BARCELLOS D. Doenças dos suínos. 2.ed. Goiania: Cânone Editorial, 2012. p.438-466. 
MARTINS, J.R.; BARCELLOS, D.E.N.; STEPAN, A.L. et al. Associação de Cryptosporidium spp. com diarreia em suínos recentemente desmamados. Acta sci. vet., v. 21, p.32-36, 1993.

MONTEIRO, S. G. Parasitologia na medicina veterinária. São Paulo: Roca, 2011. 356p.

MUNDT, H.C.; JOACHIM, A.; BECKA, M. et al. Isospora suis: an experimental model for mammalian intestinal coccidiosis. Parasitol. Res. v.98, p.167-175, 2006.

NISHI, S.M.; GENNARI, S.M.; LISBOA, M.N.T.S. et al. Parasitas intestinais em suínos confinados nos estados de São Paulo e Minas Gerais. Arq. Inst. Biol. v.67, p.199-203, 2000.

ÓZSVÁRI, L. Production impact of parasitisms and coccidiosis in swine. J. Dairy Vet. Anim. Res., v.7, p.217-222, 2018

PINTO, J.M. S.; COSTA, J.O.; SOUZA, J.C.A. Ocorrência de endoparasitos em suínos criados em Itabuna, Bahia, Brasil. Ciênc. Vet. Tróp., v.10, p.79-85, 2007.

REBOUCAS, M.M.; OLIVEIRA, S.M.,; SPÓSITO FILHA, E. et al. Isospora suis biester, 1934 em suínos no estado de São Paulo-Brasil (Apicomplexa Eimeriidae). Rev. Bras. Parasitol. Vet., v.1, p.137-140, 1992.

SARTOR, A.A.; BELLATO, V.; SOUZA, A.P et al. Prevalência das espécies de Eimeria Schneider, 1875 e Isospora Schneider, 1881 (Apicomplexa: Eimeriidae) parasitas de suínos do município de Videira, SC, Brasil. Rev. Ciênc. Agrovet. v.6, p.38-43, 2007.

SAYD, S.M.O.; KAWAZOE, U. Prevalence of porcine neonatal isosporosis in Brazil. Vet. Parasitol. v.67, p.169-174, 1996.
SHEATHER, A.T. The detection of intestinal protozoa and monge parasites by a flotation technique. J. Comp. Phatol., v.36, p.266-275, 1923.

SKAMPARDONIS, V.; SOTIRAKI, S.; KOSTOULAS, P. et al. Factors associated with the occurrence and level of Isospora suis oocyst excretion in nursing piglets of Greek farrow-tofinish herds. BMC Vet. Res., v.228, p.1-9, 2012.

SOLAYMANI-MOHAMMADI, S.; PETRI JR., W.A. Zoonotic implications of the swinetransmitted protozoal infections. Vet. Parasitol., v.140, p.189-203, 2006.

SOTIRAKI, S.; ROEPSTORFF, A.; NIELSEN, J.P. et al. Population dynamics and intra-litter transmission patterns of Isospora suis in suckling piglets under on-farm conditions. Parasitology, v.135, p.395-405, 2007.

STEENHARD, N.R.; JUNGERSEN, G.; KOKOTOVIC, B. et al. Ascaris suum infection negatively affects the response to a Mycoplasma hyopneumoniae vaccination and subsequent challenge infection in pigs. Vaccine, v.27, p.51615169, 2009.

STEFFEN, R.P.B.; SOARES, K.D.; COLVERO, L.P. et al. Prevalência do Balantidium coli nas fezes de suínos na fase de terminação em abatedouro. Agrarian, v.3, p.301-304, 2010.

TAYLOR, M.A.; COOP, R.L.; WALL, R.L. Parasitologia veterinária. 3.ed. Rio de Janeiro: Guanabara Koogan, 2010. 742p.

URQUHART, G.M. Parasitologia veterinária. 2.ed. Rio de Janeiro: Guanabara Koogan, 1998. 273p. 